\title{
EFFECT OF DIETARY LEVELS OF CRUDE PROTEIN AND SPECIFIC ORGANIC ACIDS ON BROILERS PERFORMANCE
}

\author{
Haiam S. Abd EL-Haliem, Faten A. M. Attia, Hamada S. Saber and Ismail H. Hermes \\ Animal Production Department, Faculty of Agriculture, Suez Canal University, Ismailia, Egypt, PO Box \\ 41522, Corresponding e-mail:haiam65@vahoo.com,
}

Received: 22/10/2017

SUMMARY

A study was conducted to evaluate the effects of two crude protein levels: recommended (RPL; NRC, 1994), $2 \%$ Lower (LPL) and two Organic Acids (OA; Citric, CA and Fumaric, FUA) each at 0, 1.5 and $3.0 \%$ of the diet on broilers' performance. A total number of 288 one-day old unsexed Cobb broiler chicks were allotted randomly into 12 treatments of three replicates with eight chicks each. Mash corn-soybean meal diets, with $3200 \mathrm{Kcal} / \mathrm{Kg}$, were fed. Starter diets (0-3 weeks of age) contained 23 and $21 \% \mathrm{CP}$, grower (3-5 weeks of age) contained 20 and $18 \% C P$ and finisher (at the $6^{\text {th }}$ week of age) contained 18 and $16 \% C P$. Feeding $R P L+1.5 \%$ FUA diet significantly $(P \leq 0.05)$ improved body weight. Plasma total protein, albumin, lipids and calcium levels

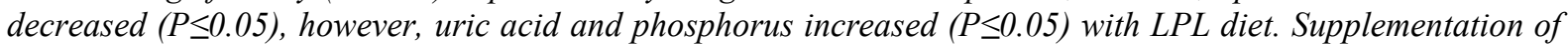

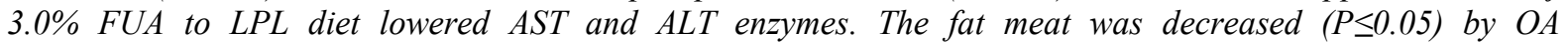
supplementations to RPL or LPL diets and the lowest was recorded for $R P L+1.5 \%$ CA. Organic acid supplementation increased $(P \leq 0.05)$ meat protein and the highest was recorded for $1.5 \%$ CA or FUA either with RPL or LPL diets. The inclusion of FUA or CA into RPL or LPL diets increased tibia ash and retention of $N$ and $P$ however, FUA was more effective than CA. In conclusion, organic acids as a feed additive in poultry production had positive effects on broiler performance fed diets differing in CP level, via maintaining birds' physiological conditions, improving meat quality and reducing $N$ and $P$ excretion.

\section{Keywords: Citric acid, fumaric acid, body weight, blood constituents, bone ash, nutrient retention}

\section{INTRODUCTION}

The principal concern of poultry producers is maximizing the economic profits via reducing the feed cost which is about $70 \%$ of the production total cost. Protein is one of the nutrient constitutes and is considered the most expensive nutrient in poultry diet. In recent years, efforts to reduce dietary protein level have been the subject of various research endeavors. There is a biological limit to the extent to which dietary crude protein level that could be reduced in the diet without any detrimental effects on the performance. Some attempts were made to lower dietary CP level without adverse effects on broiler chicks' performance (Kamran et al., 2008, Abbasi et al., 2014 and Saleh, 2016). However, in other studies, growth rate, feed efficiency and carcass composition were affected when chicks were fed diets low in CP despite the addition of specific essential amino acids and other nutrients. (Bregendahl et al., 2002 and Rashid et al., 2012). Moreover, low protein diets reduced nitrogen excretion; this would be beneficial for reducing the environmental contamination (Malomo et al., 2013 and Gheisari et al., 2015).

The European Union has banned the use of antibiotics as feed additives in poultry industry because of the fear of antibiotic resistance and its implications on human health. Therefore, supplementing low protein diets with feed additives could be an alternative approach to improve broiler chicks' performance. Such a situation has compelled the investigators to explore of other non-therapeutic substances such as; organic acids, probiotics, prebiotics, and enzymes as feed additives in poultry production. An organic acid, individually or blends, had antimicrobial activities similar to those of antibiotics (Ricke, 2003). The European Union permitted the use of organic acids and their salts in poultry diets because they are safe and have beneficial effects on performance. A favorable effect of organic acids on bacteria for improved gut health included in the diet has been reported (Ghazalah et al., 2011, Ragab et al., 2012 and Dehghani-Tafti and Jahanian, 2016). Organic acids were beneficial to broiler chicks by reducing the digesta $\mathrm{pH}$ value in the gastrointestinal tract, regulating the microbial population balance in the gut, stimulating the digestive enzyme secretion and promoting growth and recovery of the intestinal morphology (Ghazalah et al., 2011; Adil et al., 2010; Abdel-Fattah et al., 2008; Rafacz-Livingston et al., 2005). Therefore, the aim of this study was to investigate the effects of dietary crude protein: recommended (NRC, 1994), $2 \%$ lower and two organic acids (Citric or Fumaric) each at $0,1.5$ and $3.0 \%$ of the diet on broilers' body weight, specific plasma biochemical parameters, chemical composition of meat, tibia ash and excretion of nitrogen and phosphorus.

\section{MATERIALS AND METHODS}

Management, Diets and Treatments:

This study was approved by the committee of Animal Production Department, College of 
Agriculture, Suez Canal University and performed according to the relevant laws and institutional guidelines. Cobb broiler unsexed chicks (288; oneday-old) obtained from a commercial hatchery, were individually weighed, wing-banded and were randomly distributed into 12 treatments of three replicates and eight chicks each. Birds' average initial live body weight for each treatment was similar (49.75 $\pm 0.19 \mathrm{~g})$. Chicks were raised in an open house and caged in brooder batteries with wire mesh floors. Feed and fresh water were supplied $a d-$ libitum during the experiment which lasted for six weeks. The artificial light was provided daily for 23 $\mathrm{hr}$ and one $\mathrm{hr}$ of darkness throughout the experimental period. All birds were kept under the same managerial, hygienic and environmental conditions and vaccinated against the common poultry diseases.

Two levels of the crude protein: Recommended (RPL; NRC, 1994), low, LPL (2\% less) and two organic acids (Citric Acid, CA or Fumaric Acid, FUA) each at $0,1.5$ and $3.0 \%$ of the diet were studied. Chicks were fed isocaloric (3200 Kcal $\mathrm{ME} / \mathrm{Kg}$ diet) mash corn-soybean meal diets. Diets fed were the starter $(0-3$ weeks of age) contained 23 and $21 \% \mathrm{CP}$, grower (3-5 weeks of age) contained 20 and $18 \% \mathrm{CP}$ and finisher (at the $6^{\text {th }}$ week of age) contained 18 and $16 \% \mathrm{CP}$. The composition, calculated and chemical analysis (A.O.A.C, 1990) for starter, grower, and finisher diets are shown in Tables ( $1 \mathrm{~A}, \mathrm{~B}$ and $\mathrm{C})$.

Table 1.A . Composition of the experimental diet (Broiler starter diets, 0-3wk)

\begin{tabular}{|c|c|c|c|c|c|c|}
\hline \multirow{2}{*}{$\begin{array}{l}\text { Diets }(\mathrm{CP} \%) / \text { Phases } \\
\text { Ingredients } \%\end{array}$} & \multicolumn{3}{|c|}{$23(\mathrm{RPL})^{1}$} & \multicolumn{3}{|c|}{$21(\mathrm{LPL})^{2}$} \\
\hline & & & & & & \\
\hline Yellow corn & 52.13 & 50.00 & 50.00 & 57.21 & 55.80 & 53.00 \\
\hline Soybean meal 44\% & 29.44 & 29.05 & 23.97 & 26.80 & 24.75 & 24.40 \\
\hline Corn glu. meal $60 \%$ & 9.65 & 10.00 & 13.70 & 7.50 & 9.10 & 10.00 \\
\hline Veget.oil & 4.70 & 5.35 & 5.10 & 4.30 & 4.70 & 5.40 \\
\hline Limestone & 1.41 & 1.40 & 1.41 & 1.50 & 1.41 & 1.45 \\
\hline Di-Ca phosphate & 1.68 & 1.70 & 1.75 & 1.72 & 1.74 & 1.76 \\
\hline${ }^{3)}$ Vit. + min. premix & 0.30 & 0.30 & 0.30 & 0.30 & 0.30 & 0.30 \\
\hline $\mathrm{NaCl}$ & 0.40 & 0.40 & 0.40 & 0.40 & 0.40 & 0.40 \\
\hline DL- Methionine & 0.10 & 0.10 & 0.06 & 0.09 & 0.08 & 0.07 \\
\hline L-Lysine $\mathrm{HCl}$ & 0.09 & 0.10 & 0.21 & 0.08 & 0.12 & 0.12 \\
\hline Choline chloride & 0.10 & 0.10 & 0.10 & 0.10 & 0.10 & 0.10 \\
\hline 4) Organic acid level & 0 & 1.50 & 3.00 & 0 & 1.50 & 3.00 \\
\hline Total & 100 & 100 & 100 & 100 & 100 & 100 \\
\hline \multicolumn{7}{|l|}{ Calculated values $\%$} \\
\hline $\mathrm{ME}(\mathrm{Kcal} / \mathrm{Kg})$ & 3208 & 3203 & 3204 & 3202 & 3206 & 3205 \\
\hline Crude protein & 23.51 & 23.28 & 23.52 & 21.16 & 21.09 & 21.24 \\
\hline Calcium & 1.001 & 1.000 & 1.001 & 1.037 & 1.002 & 1.020 \\
\hline Inorg. Phosphorus & 0.450 & 0.450 & 0.451 & 0.451 & 0.450 & 0.451 \\
\hline \multicolumn{7}{|l|}{ Determined values $\%$} \\
\hline Moisture & 8.14 & 8.14 & 8.47 & 8.33 & 8.21 & 8.00 \\
\hline Crude protein & 22.90 & 22.75 & 22.78 & 20.71 & 20.69 & 21.06 \\
\hline Crude fiber & 3.50 & 3.51 & 3.53 & 3.59 & 3.47 & 3.75 \\
\hline Ether extract & 3.74 & 3.82 & 3.78 & 3.81 & 3.61 & 3.44 \\
\hline Ash & 7.12 & 7.25 & 7.50 & 7.69 & 7.73 & 7.33 \\
\hline Nitrogen free extract & 54.60 & 54.53 & 53.94 & 55.87 & 56.29 & 56.42 \\
\hline
\end{tabular}


Table 1.B. Composition of the experimental diet (Broiler grower diets, 3-5 wk)

\begin{tabular}{|c|c|c|c|c|c|c|}
\hline \multirow{2}{*}{$\begin{array}{l}\text { Diets }(\mathrm{CP} \%) / \text { Phases } \\
\text { Ingredients } \%\end{array}$} & \multicolumn{3}{|c|}{$20(\mathrm{RPL})^{1}$} & \multicolumn{3}{|c|}{$18(\mathrm{LPL})^{2}$} \\
\hline & & & & & & \\
\hline Yellow corn & 60.39 & 58.60 & 56.21 & 64.31 & 61.90 & 60.00 \\
\hline Soybean meal $44 \%$ & 26.00 & 23.81 & 23.49 & 26.00 & 25.07 & 24.00 \\
\hline Corn glu. meal $60 \%$ & 6.00 & 8.00 & 8.50 & 2.00 & 3.20 & 4.00 \\
\hline Veget.oil & 4.00 & 4.40 & 5.10 & 4.18 & 4.80 & 5.40 \\
\hline Limestone & 1.44 & 1.50 & 1.50 & 1.44 & 1.44 & 1.46 \\
\hline Di-Ca phosphate & 1.22 & 1.23 & 1.23 & 1.21 & 1.22 & 1.24 \\
\hline${ }^{3)} \mathrm{Vit} .+$ min. premix & 0.30 & 0.30 & 0.30 & 0.30 & 0.30 & 0.30 \\
\hline $\mathrm{NaCl}$ & 0.40 & 0.40 & 0.40 & 0.40 & 0.40 & 0.40 \\
\hline DL- Methionine & 0.03 & 0.01 & 0.01 & 0.04 & 0.03 & 0.03 \\
\hline L-Lysine $\mathrm{HCl}$ & 0.12 & 0.15 & 0.16 & 0.02 & 0.04 & 0.07 \\
\hline Choline chloride & 0.10 & 0.10 & 0.10 & 0.10 & 0.10 & 0.10 \\
\hline 4) Organic acid level & 0 & 1.50 & 3.00 & 0 & 1.50 & 3.00 \\
\hline Total & 100 & 100 & 100 & 100 & 100 & 100 \\
\hline \multicolumn{7}{|l|}{ Calculated values $\%$} \\
\hline $\mathrm{ME}(\mathrm{Kcal} / \mathrm{Kg})$ & 3206 & 3210 & 3206 & 3201 & 3208 & 3207 \\
\hline Crude protein & 20.42 & 20.56 & 20.54 & 18.11 & 18.21 & 18.06 \\
\hline Calcium & 0.902 & 0.922 & 0.920 & 0.901 & 0.900 & 0.910 \\
\hline Inorg. Phosphorus & 0.355 & 0.352 & 0.350 & 0.350 & 0.350 & 0.351 \\
\hline \multicolumn{7}{|l|}{ Determined values $\%$} \\
\hline Moisture & 8.05 & 8.05 & 8.44 & 8.11 & 8.19 & 8.30 \\
\hline Crude protein & 19.85 & 19.92 & 19.83 & 17.99 & 17.98 & 18.09 \\
\hline Crude fiber & 3.84 & 3.69 & 3.74 & 3.76 & 3.65 & 3.50 \\
\hline Ether extract & 3.49 & 3.92 & 3.63 & 3.73 & 3.67 & 3.52 \\
\hline Ash & 7.56 & 7.61 & 7.80 & 7.86 & 7.95 & 7.91 \\
\hline Nitrogen free extract & 57.21 & 56.81 & 56.56 & 58.55 & 58.56 & 58.68 \\
\hline $\begin{array}{l}{ }^{1} \text { Recommended protein ley } \\
\text { Vitamin } \mathrm{D}_{3} \text { (Cholecalcifer } \\
\text { Riboflavin, } 5.0 \mathrm{mg} \text {; Pyrido } \\
\text { Biotin, } 0.05 \mathrm{mg} \text {; Choline c } \\
{ }^{4} \text { Citric or Fumaric acids }\end{array}$ & $\begin{array}{l}{ }^{2} \text { Low } \\
\text { U; Vitan } \\
\text { ng; Cyar } \\
0 \text { mg; C }\end{array}$ & $\begin{array}{l}\text { level (LPL } \\
\text { tocophery } \\
\text { min, } 0.01 \\
\text { g; I, } 1.0 \mathrm{~m}\end{array}$ & $\begin{array}{l}\text { upplied } \mathrm{p} \\
\text { ), } 10 \mathrm{mg} \\
\text { tothenic } \\
\mathrm{mg} ; \mathrm{Zn}\end{array}$ & $\begin{array}{l}\mathrm{am} \text { of di } \\
\mathrm{K}_{3}(\mathrm{Me} \\
\mathrm{mg} ; \mathrm{Nic} \\
\mathrm{Mn}, 60 \mathrm{n}\end{array}$ & $\begin{array}{l}\text { in A (Ret } \\
2.0 \mathrm{mg} ; \\
\mathrm{d}, 30 \mathrm{mg} \\
1 \mathrm{mg} \text {; an }\end{array}$ & $\begin{array}{l}00 \mathrm{IU} ; \\
1.0 \mathrm{mg} \\
\text { id, } 1.0 \mathrm{mg} \\
\mathrm{mg} . .\end{array}$ \\
\hline
\end{tabular}

Table. 1.C. Composition of the experimental diet (Broiler finisher $\operatorname{diets,} 6^{\text {th }}$ wk)

\begin{tabular}{|c|c|c|c|c|c|c|}
\hline \multirow{2}{*}{$\begin{array}{l}\text { Diets }(\mathrm{CP} \%) / \text { Phases } \\
\text { Ingredients } \%\end{array}$} & \multicolumn{3}{|c|}{$18(\mathrm{RPL})^{1}$} & \multicolumn{3}{|c|}{$16(\mathrm{LPL})^{2}$} \\
\hline & & & & & & \\
\hline Yellow corn & 65.00 & 63.00 & 60.98 & 70.16 & 67.50 & 65.40 \\
\hline Soybean meal 44\% & 26.38 & 24.88 & 23.35 & 23.00 & 23.00 & 22.10 \\
\hline Corn glu. meal $60 \%$ & 1.50 & 3.00 & 4.50 & - & 0.50 & 1.50 \\
\hline Veget.oil & 4.00 & 4.50 & 5.00 & 3.70 & 4.36 & 4.86 \\
\hline Limestone & 1.30 & 1.31 & 1.32 & 1.32 & 1.32 & 1.33 \\
\hline Di-Ca phosphate & 1.00 & 1.00 & 1.00 & 1.00 & 1.00 & 1.00 \\
\hline${ }^{3)}$ Vit. + min. premix & 0.30 & 0.30 & 0.30 & 0.30 & 0.30 & 0.30 \\
\hline $\mathrm{NaCl}$ & 0.40 & 0.40 & 0.40 & 0.40 & 0.40 & 0.40 \\
\hline DL- Methionine & 0.02 & 0.01 & 0.01 & 0.02 & 0.02 & 0.01 \\
\hline L-Lysine $\mathrm{HCl}$ & - & - & 0.04 & - & - & - \\
\hline Choline chloride & 0.10 & 0.10 & 0.10 & 0.10 & 0.10 & 0.10 \\
\hline${ }^{4)}$ Organic acid level & 0 & 1.50 & 3.00 & 0 & 1.50 & 3.00 \\
\hline Total & 100 & 100 & 100 & 100 & 100 & 100 \\
\hline \multicolumn{7}{|l|}{ Calculated values\% } \\
\hline Crude protein & 18.07 & 18.17 & 18.29 & 16.08 & 16.16 & 16.18 \\
\hline $\mathrm{ME}(\mathrm{Kcal} / \mathrm{Kg})$ & 3202 & 3204 & 3206 & 3208 & 3207 & 3201 \\
\hline Calcium & 0.804 & 0.803 & 0.802 & 0.803 & 0.803 & 0.802 \\
\hline Inorg. Phosphorus & 0.312 & 0.308 & 0.305 & 0.305 & 0.304 & 0.301 \\
\hline \multicolumn{7}{|l|}{ Determined values $\%$} \\
\hline Moisture & 7.72 & 8.02 & 8.01 & 7.95 & 8.15 & 7.90 \\
\hline Crude protein & 17.89 & 17.92 & 17.87 & 15.96 & 15.75 & 15.85 \\
\hline Crude fiber & 3.75 & 3.53 & 3.55 & 3.83 & 3.58 & 3.47 \\
\hline Ether extract & 3.54 & 3.44 & 3.57 & 3.44 & 3.68 & 3.70 \\
\hline Ash & 6.12 & 5.97 & 5.90 & 7.83 & 7.80 & 7.98 \\
\hline Nitrogen free extract & 60.98 & 61.12 & 61.10 & 60.99 & 61.04 & 61.10 \\
\hline
\end{tabular}




\section{Growth Criteria}

During the experimental period, bird's individual live body weights were recorded weekly using a sensitive digital scale. Feed intake was recorded at the end of the experiment. Also, mortality obtained and viability was calculated. The European Production Efficiency Factor (EPEF) was estimated according to Marcu et al. (2013) with the following formula:

$$
\mathrm{EPEF}=\frac{\text { Live bodyweight }(\mathrm{kg}) \times \text { Livability }(\%)}{\text { age }(\text { days }) \times \mathrm{FCR}(\mathrm{kg} \text { feed } / \mathrm{Kg} \mathrm{gain})} * 100
$$

\section{Plasma Biochemical Constituents:}

At the end of the experiment, two birds were chosen close to the average body weight from each replicate (six birds per treatment). Birds were fasted of feed overnight with free access to water. Selected birds slaughtered by slitting the jugular vein and blood samples were collected from each bird in a heparinized tube. Plasma was separated by centrifugation of the blood samples at $3000 \mathrm{rpm}$ for 15 minutes and stored at $-20^{\circ} \mathrm{C}$ until analysis. Total protein, albumin, total lipids, cholesterol, uric acid, calcium, phosphorus, and liver enzymes activity (Aspartate Aminotransferase, AST and Alanine Aminotransferase, ALT) were determined colorimetrically using commercial kits (Young and Friedman, 2001).

\section{Meat Chemical Composition:}

Eviscerated carcass from each bird was deboned; meat was minced and stored at $-20^{\circ} \mathrm{C}$ until being analysis. The chemical composition of meat was done according to AOAC (1990) methods. Dry matter was determined by drying meat samples in an oven at $105^{\circ} \mathrm{C}$ for 6 hours or until reaching the constant weight. Nitrogen was determined by the Kjeldahl method and crude protein was calculated by multiplying nitrogen times 6.25. Crude fat was determined using extraction with petroleum ether by Soxhlet method. Ash content was determined by ashing the sample at $550^{\circ} \mathrm{C}$ until reaching constant weight, by a muffle furnace oven. Nitrogen-free extract (NFE) was calculated by difference.

\section{Bone Ash:}

The right tibia of each carcass was cleaned of adhering tissues and dried in an oven at $70^{\circ} \mathrm{C}$ for 24 hr or until reaching a constant weight. The dried tibias were extracted of oil using petroleum ether by Soxhlet method, dried and weighed. The fat-free dry tibia was ashed in a muffle furnace at $550^{\circ} \mathrm{C}$ for 24 $\mathrm{hr}$ or until reaching a constant weight and ash weighed. Tibia fat-free weight and tibia ash weight were used to calculate tibia ash percentage.

\section{Digestibility Trial:}

A digestion trial was performed at the end of the performance trial ( 6 weeks of age) to determine total apparent retention of nitrogen and phosphorus. Four birds were chosen from each treatment close to the average body weight, housed individually in digestion cages and fed the equivalent finishing diet. Seven days for adaptation to the cage experimental condition and three days for total collection were applied. Feed intake and faecal samples were accurately determined. Faecal samples from each bird were collected daily, cleaned from feathers and feed, then pooled and stored at $-20^{\circ} \mathrm{C}$ until further process. The collected faecal samples were dried in an air forced oven at $70^{\circ} \mathrm{C}$ for $24 \mathrm{hr}$ or until reaching a constant weight. The dried faecal samples were weighed, ground and placed in glass jars until chemical analyses. Crude protein and phosphorus were determined in the experimental diets and excreta as described by A.O.A.C. (1990).

\section{Statistical Analysis}

The statistical analysis of data was performed using general linear models procedure of SAS (SAS Institute Inc., 2006). A factorial arrangement used, including two crude protein levels (PL), two organic acid types (OAT) and three organic acid levels $(\mathrm{OAL})$. The model used was as follows:

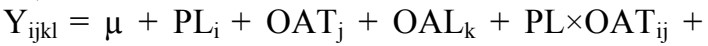
$\mathrm{PL} \times \mathrm{OAL}_{\mathrm{ik}}+\mathrm{OAT} \times \mathrm{OAL}_{\mathrm{jk}}+\mathrm{PL} \times \mathrm{OAT} \times \mathrm{OAL}_{\mathrm{ijk}}+\mathrm{e}_{\mathrm{ijk}}$ Where: $\mathrm{Y}_{\mathrm{ijkl}}=$ observed value, $\mu=$ the overall mean, $\mathrm{PL}_{\mathrm{i}}=$ effect of protein levels $(\mathrm{i}=$ recommended and low), $\mathrm{OAT}_{\mathrm{j}}=$ effect of organic acid types $(\mathrm{j}=$ citric and fumaric), $\mathrm{OAL}_{\mathrm{k}}=$ effect of organic acid levels $\left(\mathrm{k}=0,1.5\right.$ and $3.0 \%$ of the diet), $\mathrm{PL} \times \mathrm{OAT}_{\mathrm{ij}}=$ the interaction between $\mathrm{i}^{\text {th }}$ protein levels and $\mathrm{j}^{\text {th }}$ organic acid types, $\mathrm{PL} \times \mathrm{OAL}_{\mathrm{ik}}=$ the interaction between $\mathrm{i}^{\text {th }}$ protein levels and $\mathrm{k}^{\text {th }}$ organic acid levels, $\mathrm{OAT} \times \mathrm{OAL}_{\mathrm{jk}}=$ the interaction between $\mathrm{j}^{\text {th }}$ organic acid types and $\mathrm{k}^{\text {th }}$ organic acid levels, $\mathrm{PL} \times \mathrm{OAT} \times \mathrm{OAL}_{\mathrm{ijk}}=$ the interaction between $\mathrm{i}^{\text {th }}$ protein levels, $\mathrm{j}^{\text {th }}$ organic acid types and $\mathrm{k}^{\text {th }}$ organic acid levels and $\mathrm{e}_{\mathrm{ijkl}}=$ experimental random error. Means comparisons were performed using Duncan's multiple range test (Duncan, 1955). The standard error of the means (SEM) used to express the variation in the data. A probability level of $\mathrm{P} \leq 0.05$ was considered statistically significant.

\section{RESULTS}

\section{Growth Criteria}

Body weight data (BW, Table 2) indicated that diet with the recommended protein level (RPL) significantly increased BW compared to the low protein level (LPL) diet during the experimental period. However, the European Production Efficiency Factor (EPEF) was not affected. Also, there were no significant $(\mathrm{P} \leq 0.05)$ effects of dietary Citric Acid (CA) or Fumaric Acid (FUA) on BW and EPEF. As Organic Acid Levels (OAL) changed, significant $(\mathrm{P} \leq 0.05)$ differences were observed for $\mathrm{BW}$ (at the first, third and fifth weeks) and EPEF at the end of the experiment. Broilers fed with diets supplemented with $1.5 \%$ OA recorded the highest 
BW and EPEF throughout the experimental period. Also, broilers fed diet containing RPL $+1.5 \% \mathrm{CA}$ diet had the highest significant $(\mathrm{P} \leq 0.05)$ body weight at the $1^{\text {st }}$ and $3^{\text {rd }}$ weeks of age, however, at the $5^{\text {th }}$ and $6^{\text {th }}$ weeks of age, RPL $+1.5 \%$ FUA diet improved BW compared to most of the treatments. The lowest BW recorded with LPL diet $+0 \%$ OA at the $1^{\text {st }}$ and $3^{\text {rd }}$ weeks of age. Besides, LPL $+3.0 \%$ CA diet reduced $\mathrm{BW}$ at the $5^{\text {th }}$ and $6^{\text {th }}$ weeks of age. For the EPEF, the highest significant value was recorded with RPL $+1.5 \%$ FUA followed by RPL $+1.5 \%$ CA compared with RPL $+0 \%$ OA.

Table 2. Effect of dietary protein levels (PL), organic acid types (OAT) and organic acid levels (OAL) on live body weight (g/bird) and European production efficiency factor (EPEF) of broiler chicks

\begin{tabular}{|c|c|c|c|c|c|c|c|}
\hline \multirow{2}{*}{ Traits } & & & \multicolumn{2}{|c|}{ Starter } & \multirow{2}{*}{$\begin{array}{c}\text { Grower } \\
5 \mathrm{wk}\end{array}$} & \multirow{2}{*}{$\begin{array}{c}\text { Finisher } \\
6 \mathrm{wk}\end{array}$} & \multirow[t]{2}{*}{ EPEF } \\
\hline & & & $1 \mathrm{wk}$ & $3 \mathrm{wk}$ & & & \\
\hline \multicolumn{8}{|c|}{ Main Effects } \\
\hline \multirow{2}{*}{\multicolumn{2}{|c|}{${ }^{1} \mathrm{PL}$}} & $\mathrm{R}$ & $182^{\mathrm{a}} \pm 1.7$ & $880^{\mathrm{a}} \pm 7.5$ & $1751^{\mathrm{a}} \pm 16.7$ & $2158^{\mathrm{a}} \pm 19.0$ & $328.76 \pm 13.75$ \\
\hline & & $\mathrm{L}$ & $177^{\mathrm{b}} \pm 1.8$ & $826^{\mathrm{b}} \pm 8.9$ & $1664^{\mathrm{b}} \pm 16.9$ & $2055^{b} \pm 20.6$ & $315.41 \pm 7.97$ \\
\hline \multicolumn{2}{|l|}{ P-value } & & 0.0234 & $<.0001$ & 0.0002 & 0.0003 & 0.3392 \\
\hline \multirow{2}{*}{\multicolumn{2}{|c|}{${ }^{2} \mathrm{OAT}$}} & $\mathrm{CA}$ & $179.0 \pm 1.8$ & $858 \pm 8.6$ & $1702 \pm 16.8$ & $2104 \pm 20.5$ & $324.86 \pm 10.79$ \\
\hline & & FUA & $180.2 \pm 1.8$ & $849 \pm 8.4$ & $1709 \pm 17.8$ & $2103 \pm 20.4$ & $319.32 \pm 11.85$ \\
\hline \multicolumn{2}{|l|}{ P-value } & & 0.6316 & 0.9312 & 0.7683 & 0.9188 & 0.6893 \\
\hline \multirow{3}{*}{\multicolumn{2}{|c|}{${ }^{3} \mathrm{OAL}(\%)$}} & 0 & $174^{\mathrm{b}} \pm 2.1$ & $846^{\mathrm{ab}} \pm 9.3$ & $1726^{\mathrm{a}} \pm 18.1$ & $2114^{\mathrm{ab}} \pm 20.4$ & $291.30^{\mathrm{b}} \pm 14.96$ \\
\hline & & 1.5 & $183^{\mathrm{a}} \pm 2.3$ & $872^{\mathrm{a}} \pm 10.9$ & $1734^{\mathrm{a}} \pm 22.8$ & $2136^{a} \pm 28.1$ & $351.29^{\mathrm{a}} \pm 10.59$ \\
\hline & & 3 & $182^{\mathrm{a}} \pm 1.9$ & $842^{\mathrm{b}} \pm 10.9$ & $1661^{b} \pm 20.9$ & $2065^{\mathrm{b}} \pm 24.4$ & $323.66^{\mathrm{ab}} \pm 9.87$ \\
\hline \multicolumn{3}{|l|}{ P-value } & 0.0015 & 0.0561 & 0.0141 & 0.0841 & 0.0059 \\
\hline R.PL & $\mathrm{CA}$ & 0 & $178^{\mathrm{abcd}} \pm 4.5$ & $888^{\mathrm{ab}} \pm 14.4$ & $1777^{\mathrm{ab}} \pm 37.9$ & $2134^{\mathrm{ab}} \pm 42.0$ & $271.51^{\mathrm{b}} \pm 41.82$ \\
\hline R.PL & $\mathrm{CA}$ & 1.5 & $191^{\mathrm{a}} \pm 3.4$ & $927^{\mathrm{a}} \pm 13.9$ & $1745^{\mathrm{abc}} \pm 34.7$ & $2201^{\mathrm{ab}} \pm 42.0$ & $369.17^{\mathrm{a}} \pm 5.89$ \\
\hline R.PL & $\mathrm{CA}$ & 3 & $177^{\mathrm{bcd}} \pm 4.1$ & $839^{b c} \pm 21.5$ & $1717^{\mathrm{abc}} \pm 38.3$ & $2143^{\mathrm{ab}} \pm 44.3$ & $342.78^{\mathrm{ab}} \pm 16.95$ \\
\hline R.PL & FUA & 0 & $178^{\mathrm{abcd}} \pm 4.5$ & $888^{\mathrm{ab}} \pm 14.4$ & $1777^{\mathrm{ab}} \pm 33.9$ & $2134^{\mathrm{ab}} \pm 42.0$ & $271.51^{\mathrm{b}} \pm 41.82$ \\
\hline R.PL & FUA & 1.5 & $187^{\mathrm{ab}} \pm 5.0$ & $899^{\mathrm{ab}} \pm 20.8$ & $1841^{\mathrm{a}} \pm 46.8$ & $2256^{\mathrm{a}} \pm 48.6$ & $382.02^{\mathrm{a}} \pm 10.04$ \\
\hline R.PL & FUA & 3 & $182^{\mathrm{abc}} \pm 3.3$ & $842^{b c} \pm 18.4$ & $1669^{\text {bcd }} \pm 40.2$ & $2075^{\text {bcd }} \pm 47.8$ & $335.58^{\mathrm{ab}} \pm 9.04$ \\
\hline L.PL & $\mathrm{CA}$ & 0 & $169^{\mathrm{d}} \pm 3.8$ & $804^{\mathrm{c}} \pm 19.1$ & $1686^{\mathrm{bcd}} \pm 24.7$ & $2099^{\text {bcd }} \pm 40.4$ & $311.09^{\mathrm{ab}} \pm 17.96$ \\
\hline L.PL & $\mathrm{CA}$ & 1.5 & $172^{\text {cd }} \pm 4.4$ & $843^{b c} \pm 20.5$ & $1726^{\mathrm{abc}} \pm 41.2$ & $2118^{\mathrm{abc}} \pm 55.9$ & $343.71^{\mathrm{ab}} \pm 2.96$ \\
\hline L.PL & $\mathrm{CA}$ & 3 & $188^{\mathrm{ab}} \pm 4.0$ & $845^{\mathrm{bc}} \pm 26.1$ & $1584^{\mathrm{d}} \pm 49.2$ & $1951^{\mathrm{d}} \pm 55.8$ & $310.88^{\mathrm{ab}} \pm 14.55$ \\
\hline L.PL & FUA & 0 & $169^{\mathrm{d}} \pm 3.8$ & $804^{\mathrm{c}} \pm 19.1$ & $1686^{\mathrm{bcd}} \pm 33.3$ & $2099^{\mathrm{bcd}} \pm 40.4$ & $311.09^{\mathrm{ab}} \pm 17.96$ \\
\hline L.PL & FUA & 1.5 & $182^{\mathrm{abc}} \pm 4.6$ & $822^{\mathrm{c}} \pm 23.1$ & $1628^{\mathrm{cd}} \pm 49.4$ & $1974^{\mathrm{cd}} \pm 59.4$ & $310.27^{\mathrm{ab}} \pm 28.61$ \\
\hline L.PL & FUA & 3 & $183^{\mathrm{abc}} \pm 3.8$ & $840^{\mathrm{bc}} \pm 22.1$ & $1675^{\mathrm{bcd}} \pm 35.4$ & $1675^{\mathrm{bcd}} \pm 35.4$ & $305.42^{\mathrm{ab}} \pm 25.91$ \\
\hline \multicolumn{3}{|l|}{ SEM } & \pm 1.24 & \pm 6.002 & \pm 12.21 & \pm 14.42 & \pm 7.9111 \\
\hline \multicolumn{3}{|l|}{ P-value } & 0.0005 & $<.0001$ & 0.0009 & 0.0005 & 0.0664 \\
\hline \multicolumn{3}{|c|}{ Interactions } & & & P-value & & \\
\hline \multicolumn{3}{|c|}{ PL X OAT } & 0.8205 & 0.9954 & 0.7014 & 0.9522 & 0.5926 \\
\hline \multicolumn{3}{|c|}{ PL X OAL } & 0.0049 & 0.0028 & 0.6501 & 0.0953 & 0.0348 \\
\hline \multicolumn{3}{|c|}{ OAT X OAL } & 0.8451 & 0.6189 & 0.9037 & 0.4746 & 0.9533 \\
\hline \multicolumn{3}{|c|}{ PL X OAT X OAL } & 0.1117 & 0.9613 & 0.0134 & 0.0096 & 0.7222 \\
\hline
\end{tabular}

\footnotetext{
${ }^{1}$ PL: Protein Level (Recommended, RPL or Low, LPL)

${ }^{2}$ OAT: Organic Acid Type (CA, Citric Acid \& FUA, Fumaric Acid)

${ }^{3}$ OAL: Organic Acid Level $(0,1.5$ \& 3\%).
}

Means with no different within the column of each classification (PL, OAT, OAL or combined effects) are significantly $(\mathrm{P} \leq 0.05)$ different

\section{Plasma Biochemical Constituents:}

Table (3) showed that plasma total protein, albumin, total lipids and calcium concentrations were significantly higher $(\mathrm{P} \leq 0.05)$ while uric acid and phosphorus were lower $(\mathrm{P} \leq 0.05)$ for broilers fed $\mathrm{RPL}$ compared to LPL diets. However, there was no treatment effect on cholesterol, AST and ALT. Plasma total protein, uric acid and calcium levels significantly $(\mathrm{P} \leq 0.05)$ increased while albumin and phosphorus decreased due to dietary $\mathrm{CA}$ in comparison with FUA. Total lipids, cholesterol, AST and ALT were not affected by organic acid type (OAT) supplementation. Plasma constituents were affected $(\mathrm{P} \leq 0.05)$ due to the OAL except for total lipids and ALT. Organic acids at 1.5 and $3.0 \%$ increased $(\mathrm{P} \leq 0.05)$ total protein, uric acid, and phosphorus while reduced $(\mathrm{P} \leq 0.05)$ AST levels compared with $0 \%$ OA. Supplementation of $3.0 \%$ OA increased $(\mathrm{P} \leq 0.05)$ albumin and calcium while decreased $(\mathrm{P} \leq 0.05)$ cholesterol and AST in comparison with that of the 0 or $1.5 \% \mathrm{OA}$. 
Table 3. Effect of dietary protein levels (PL), organic acid types (OAT) and organic acid levels (OAL) on blood plasma constituents of broiler chicks at $\mathbf{4 2}$ days of age

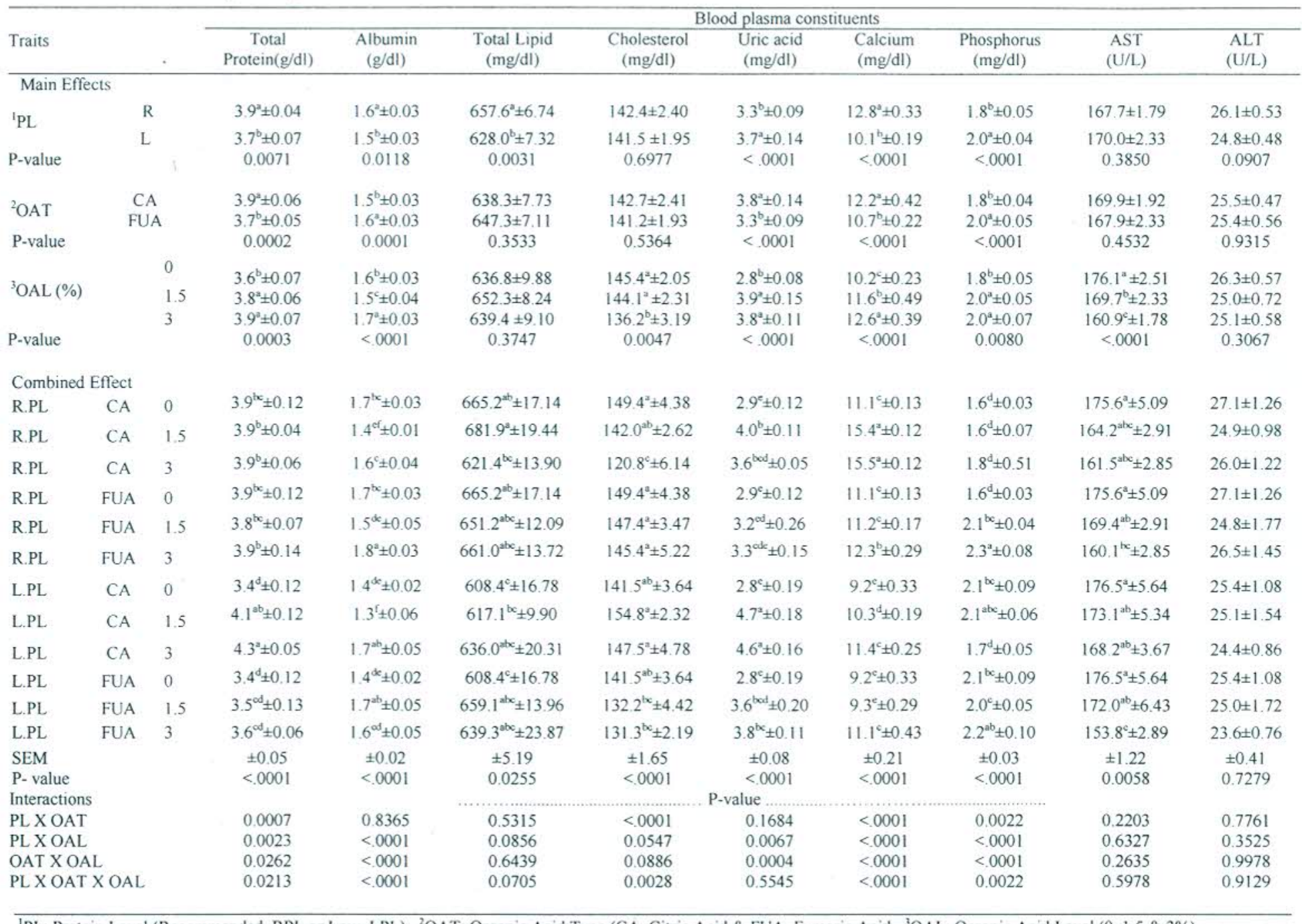

'PL: Protein Level (Recommended, RPL or Low, LPL) ${ }^{2}$ OAT: Organic Acid Type (CA, Citric Acid \& FUA, Fumaric Acid ${ }^{3}$ OAL: Organic Acid Level (0, 1.5 \& $3 \%$ ).

Means with different superscripts within the column of each classification ( $\mathrm{PL}, \mathrm{OAT}$, OAL or combined effects) are significantly $(\mathrm{P} \leq 0.05)$ different 
There were significant $(\mathrm{P} \leq 0.05)$ differences due to the combined effects of crude PL, OAT and OAL on plasma constituents except for ALT levels (Table 3) but data failed to show clear trends or specific direction. Supplementation of citric acid to LPL diet increased plasma total protein compared to the rest of the treatments with a significant difference at 3.0\% only. However, albumin level was the highest $(\mathrm{P} \leq 0.05)$ with RPL $+3.0 \%$ FUA diet while $\mathrm{LPL}+1.5 \%$ $\mathrm{CA}$ diet recorded the lowest. Plasma total lipids increased $(\mathrm{P} \leq 0.05)$ by $\mathrm{RPL}+1.5 \% \mathrm{CA}$ diet compared to the rest of the treatments. Significant reduction in plasma cholesterol levels resulted by RPL $+3.0 \% \mathrm{CA}$ and LPL+ 1.5 or $3.0 \%$ FUA diets in comparison to the rest of the treatments. Acidification of diets (RPL or LPL) with CA or FUA (1.5 or $3.0 \%$ ) increased plasma uric acid levels with significant differences only by CA compared with $0 \%$ OA diets. Plasma $\mathrm{Ca}$ levels increased $(\mathrm{P} \leq 0.05)$ when RPL or LPL diets supplemented with CA $(1.5 \& 3.0 \%)$ and $3 \%$ FUA to RPL diet. The inclusion of FUA (1.5 \& $3.0 \%)$ to RPL diet increased $(\mathrm{P} \leq 0.05)$ plasma phosphorus levels in comparison with most of the treatments. Supplementation of CA or FUA to RPL or LPL diet lowered liver enzymes with significant differences reported only for AST enzyme. The lowest AST
$(\mathrm{P} \leq 0.05)$ and ALT plasma concentrations recorded with LPL+3.0\% FUA diet.

\section{Meat Chemical Composition:}

No effect of PL was observed on the content (\%) of moisture, protein and nitrogen-free extract (NFE) of broiler chicks' meat; however, fat and ash percentages were significantly affected (Table 4). Low PL diets resulted in higher $(\mathrm{P} \leq 0.05)$ fat deposition and lower ash in broiler chicks' meat in comparison with RPL diets. The chemical composition of chicks' meat was not significantly affected by OAT. Moisture, protein and fat percentages were significantly affected by OAL. Moisture (at $1.5 \& 3.0 \%$ ) and protein (at 3.0\%) were increased $(\mathrm{P} \leq 0.05)$ and fat content (at 1.5 and $3.0 \%$ ) was significantly decreased. There were significant differences due to the combined effects of PL, OAT and OAL on the chemical composition of chicks' meat (Table 4). In general, acidification of RPL or LPL diets with CA or FUA (1.5 and 3.0\%) increased moisture, protein, ash and NFE and reduced fat content $(\%)$ of chicks' meat. Moisture and protein increased significantly by RPL $+1.5 \%$ FUA and LPL $+1.5 \%$ CA diets, respectively, while the highest ash and NFE obtained with RPL $+1.5 \% \mathrm{CA}$ in comparison with the rest of the treatments. The lowest $(\mathrm{P} \leq 0.05)$ fat percentage resulted from RPL $+1.5 \% \mathrm{CA}$ while the highest resulted from LPL $+0 \%$ OA diets (Table 4 ).

Table 4. Effect of dietary protein levels (PL), organic acid types (OAT) and organic acid levels (OAL) on chemical composition of broiler chicks' meat at 42 days of age

\begin{tabular}{|c|c|c|c|c|c|c|c|}
\hline \multirow[t]{2}{*}{ Traits } & & & \multicolumn{5}{|c|}{ Chemical analysis of meat (\%) } \\
\hline & & & Moisture & Protein & Fat & Ash & NFE \\
\hline \multicolumn{8}{|l|}{ Main Effects } \\
\hline \multirow{2}{*}{${ }^{1} \mathrm{PL}$} & & $\mathrm{R}$ & $6.31 \pm 0.02$ & $55.84 \pm 0.09$ & $34.82^{\mathrm{b}} \pm 0.11$ & $2.30^{\mathrm{a}} \pm 0.05$ & $0.73 \pm 0.04$ \\
\hline & & $\mathrm{L}$ & $6.25 \pm 0.03$ & $55.74 \pm 0.09$ & $35.35^{\mathrm{a}} \pm 0.11$ & $2.00^{\mathrm{b}} \pm 0.04$ & $0.67 \pm 0.03$ \\
\hline \multirow[t]{2}{*}{ P-value } & & & 0.0247 & 0.4416 & $<.0001$ & $<.0001$ & 0.2544 \\
\hline & & $\mathrm{CA}$ & $6.27 \pm 0.02$ & $55.81 \pm 0.09$ & $35.04 \pm 0.13$ & $2.16 \pm 0.05$ & $0.72 \pm 0.04$ \\
\hline${ }^{2} \mathrm{OAT}$ & & FUA & $6.29 \pm 0.03$ & $55.77 \pm 0.09$ & $35.12 \pm 0.11$ & $2.13 \pm 0.05$ & $0.68 \pm 0.04$ \\
\hline \multirow[t]{2}{*}{ P-value } & & & 0.4717 & 0.6893 & 0.3132 & 0.55 & 0.3082 \\
\hline & & 0 & $6.20^{\mathrm{c}} \pm 0.02$ & $55.36^{\mathrm{b}} \pm 0.06$ & $35.68^{\mathrm{a}} \pm 0.07$ & $2.07 \pm 0.05$ & $0.69 \pm 0.03$ \\
\hline \multirow[t]{2}{*}{${ }^{3} \mathrm{OAL}(\%)$} & & 1.5 & $6.43^{\mathrm{a}} \pm 0.03$ & $56.31^{\mathrm{a}} \pm 0.14$ & $34.30^{c} \pm 0.14$ & $2.20 \pm 0.07$ & $0.76 \pm 0.05$ \\
\hline & & 3 & $6.32^{\mathrm{b}} \pm 0.04$ & $56.12^{\mathrm{a}} \pm 0.09$ & $34.65^{b} \pm 0.12$ & $2.24 \pm 0.05$ & $0.67 \pm 0.05$ \\
\hline P-value & & & $<.0001$ & $<.0001$ & $<.0001$ & 0.06 & 0.3017 \\
\hline R.PL & $\mathrm{CA}$ & 0 & $6.20^{\mathrm{de}} \pm 0.03$ & $55.43^{b c} \pm 0.14$ & $35.40^{\mathrm{ab}} \pm 0.11$ & $2.24^{\mathrm{abc}} \pm 0.11$ & $0.73^{\mathrm{b}} \pm 0.08$ \\
\hline R.PL & $\mathrm{CA}$ & 1.5 & $6.44^{\mathrm{abc}} \pm 0.03$ & $56.17^{\mathrm{a}} \pm 0.34$ & $33.84^{\mathrm{e}} \pm 0.28$ & $2.56^{\mathrm{a}} \pm 0.16$ & $0.99^{\mathrm{a}} \pm 0.08$ \\
\hline R.PL & $\mathrm{CA}$ & 3 & $6.38^{\mathrm{abcd}} \pm 0.02$ & $56.28^{\mathrm{a}} \pm 0.16$ & $34.46^{\mathrm{cd}} \pm 0.19$ & $2.25^{\mathrm{abc}} \pm 0.05$ & $0.64^{\mathrm{b}} \pm 0.09$ \\
\hline R.PL & FUA & 0 & $6.20^{\mathrm{de}} \pm 0.03$ & $55.43^{b c} \pm 0.14$ & $35.40^{\mathrm{ab}} \pm 0.11$ & $2.24^{\mathrm{abc}} \pm 0.11$ & $0.73^{\mathrm{b}} \pm 0.08$ \\
\hline R.PL & FUA & 1.5 & $6.53^{\mathrm{a}} \pm 0.04$ & $56.34^{\mathrm{a}} \pm 0.21$ & $34.15^{\mathrm{de}} \pm 0.23$ & $2.29^{\mathrm{abc}} \pm 0.09$ & $0.69^{\mathrm{b}} \pm 0.08$ \\
\hline R.PL & FUA & 3 & $6.34^{\text {bcde }} \pm 0.08$ & $56.26^{\mathrm{a}} \pm 0.22$ & $34.48^{\mathrm{cd}} \pm 0.20$ & $2.37^{\mathrm{ab}} \pm 0.05$ & $0.62^{\mathrm{b}} \pm 0.08$ \\
\hline L.PL & $\mathrm{CA}$ & 0 & $6.19^{\mathrm{e}} \pm 0.04$ & $55.30^{c} \pm 0.11$ & $35.97^{\mathrm{a}} \pm 0.10$ & $1.91^{\mathrm{c}} \pm 0.09$ & $0.64^{\mathrm{b}} \pm 0.05$ \\
\hline L.PL & $\mathrm{CA}$ & 1.5 & $6.28^{\mathrm{cde}^{\prime}} \pm 0.07$ & $56.48^{\mathrm{a}} \pm 0.26$ & $34.53^{\mathrm{cd}} \pm 0.22$ & $2.03^{b c} \pm 0.08$ & $0.69^{b} \pm 0.09$ \\
\hline L.PL & $\mathrm{CA}$ & 3 & $6.32^{\text {bcde }} \pm 0.10$ & $56.27^{\mathrm{a}} \pm 0.22$ & $34.75^{\mathrm{cd}} \pm 0.34$ & $2.18^{\mathrm{bc}} \pm 0.11$ & $0.68^{\mathrm{b}} \pm 0.09$ \\
\hline L.PL & FUA & 0 & $6.19^{\mathrm{e}} \pm 0.04$ & $55.30^{c} \pm 0.11$ & $35.97^{\mathrm{a}} \pm 0.10$ & $1.91^{\mathrm{c}} \pm 0.09$ & $0.64^{\mathrm{b}} \pm 0.05$ \\
\hline L.PL & FUA & 1.5 & $6.46^{\mathrm{ab}} \pm 0.05$ & $56.25^{\mathrm{a}} \pm 0.36$ & $34.68^{\mathrm{cd}} \pm 0.32$ & $1.94^{\mathrm{c}} \pm 0.15$ & $0.67^{\mathrm{b}} \pm 0.06$ \\
\hline L.PL & FUA & 3 & $6.23^{\mathrm{de}} \pm 0.11$ & $55.93^{\mathrm{ab}} \pm 0.11$ & $34.93^{b c} \pm 0.23$ & $2.17^{\mathrm{bc}} \pm 0.11$ & $0.74^{\mathrm{b}} \pm 0.09$ \\
\hline SEM & & & \pm 0.02 & \pm 0.07 & \pm 0.08 & \pm 0.04 & \pm 0.02 \\
\hline P-value & & & $<.0001$ & $<.0001$ & $<.0001$ & 0.0011 & 0.2367 \\
\hline Interactions & & & & P-v & & & \\
\hline PL X OAT & & & 0.8854 & 0.5149 & 0.9899 & 0.8910 & 0.1955 \\
\hline PL X OAL & & & 0.3724 & 0.5062 & 0.6803 & 0.2268 & 0.1478 \\
\hline OAT X OAL & & & 0.0672 & 0.9145 & 0.6542 & 0.3755 & 0.2678 \\
\hline PL X OAT X OAL & & & 0.6732 & 0.7498 & 0.8577 & 0.6708 & 0.4450 \\
\hline
\end{tabular}

${ }^{1}$ PL: Protein Level (Recommended, RPL or Low, LPL) ${ }^{2}$ OAT: Organic Acid Type (CA, Citric Acid \& FUA, Fumaric Acid)

${ }^{3}$ OAL: Organic Acid Level (0, 1.5 \& 3\%).

Means with different superscripts within the column of each classification (PL, OAT, OAL or combined effects) are significantly (P $\leq 0.05$ ) different. 


\section{Excretion and Retention of $N$ and $P$ :}

Recommended PL significantly increased retention and reduced excretion of $\mathrm{N}$ and $\mathrm{P}$ compared with LPL diets (Table 5). The lowest $(\mathrm{P} \leq 0.05)$ excretion and the highest $(\mathrm{P} \leq 0.05)$ retention of $\mathrm{N}$ and $\mathrm{P}$ recorded with $3.0 \% \mathrm{OA}$ followed by $1.5 \% \mathrm{OA}$ diets compared with un-acidified diets. However, OAT did not affect the excretion and retention of $\mathrm{N}$ and $\mathrm{P}$. There were significant differences due to dietary PL, OAT and OAL on $\mathrm{N}$ and $\mathrm{P}$ excretion and retention. Recommended PL $+3.0 \%$ FUA diets recorded the lowest and the highest values of $\mathrm{N}$ and $\mathrm{P}$ excretion and retention, respectively followed by $\mathrm{RPL}+3.0 \% \mathrm{CA}$ diet compared to $\mathrm{LPL}+0 \% \mathrm{OA}$ diet.

Table 5. Effect of dietary protein levels (PL), organic acid types (OAT) and organic acid levels (OAL) on excretion and retention of nitrogen and phosphorus and tibia ash of broiler chicks

\begin{tabular}{|c|c|c|c|c|c|c|c|}
\hline \multirow{2}{*}{ Traits } & & & \multicolumn{2}{|c|}{ Excretion } & \multicolumn{2}{|c|}{ Retention } & \multirow[t]{2}{*}{ Tibia ash\% } \\
\hline & & & Nitrogen \% & Phosphorous \% & Nitrogen $\%$ & Phosphorous \% & \\
\hline \multicolumn{8}{|c|}{ Main Effects } \\
\hline \multirow{2}{*}{${ }^{1} \mathrm{PL}$} & & $\mathrm{R}$ & $35.46^{\mathrm{b}} \pm 1.33$ & $70.25^{\mathrm{b}} \pm 2.65$ & $64.55^{\mathrm{a}} \pm 1.33$ & $29.75^{\mathrm{a}} \pm 2.65$ & $29.48^{\mathrm{a}} \pm 0.18$ \\
\hline & & $\mathrm{L}$ & $43.50^{\mathrm{a}} \pm 2.78$ & $77.54^{\mathrm{a}} \pm 1.43$ & $56.50^{\mathrm{b}} \pm 2.78$ & $22.46^{\mathrm{b}} \pm 1.43$ & $28.99^{\mathrm{b}} \pm 0.18$ \\
\hline \multirow{2}{*}{\multicolumn{2}{|c|}{ P-value }} & & 0.0026 & 0.0011 & 0.0026 & 0.0011 & 0.0861 \\
\hline & & $\mathrm{CA}$ & $40.31 \pm 1.84$ & $75.79 \pm 1.71$ & $59.69 \pm 1.84$ & $24.22 \pm 1.71$ & $29.11 \pm 0.16$ \\
\hline${ }^{2} \mathrm{OAT}$ & & FUA & $38.64 \pm 2.81$ & $72.00 \pm 2.70$ & $61.36 \pm 2.81$ & $28.00 \pm 2.70$ & $29.36 \pm 0.19$ \\
\hline \multicolumn{2}{|l|}{$\mathrm{P}$-value } & & 0.4932 & 0.0654 & 0.4932 & 0.0654 & 0.1823 \\
\hline \multirow{3}{*}{\multicolumn{2}{|c|}{${ }^{3} \mathrm{OAL}(\%)$}} & 0 & $46.64^{\mathrm{a}} \pm 2.61$ & $79.34^{\mathrm{a}} \pm 1.69$ & $53.36^{c} \pm 2.61$ & $20.67^{\mathrm{b}} \pm 1.69$ & $28.77^{\mathrm{b}} \pm 0.13$ \\
\hline & & 1.5 & $39.49^{\mathrm{b}} \pm 1.63$ & $76.87^{\mathrm{a}} \pm 1.60$ & $60.51^{\mathrm{b}} \pm 1.63$ & $23.13^{\mathrm{b}} \pm 1.60$ & $29.42^{\mathrm{a}} \pm 0.25$ \\
\hline & & 3 & $32.30^{\mathrm{c}} \pm 2.76$ & $65.47^{\mathrm{b}} \pm 3.05$ & $67.70^{\mathrm{a}} \pm 2.76$ & $34.53^{\mathrm{a}} \pm 3.05$ & $29.99^{\mathrm{a}} \pm 0.29$ \\
\hline \multicolumn{2}{|l|}{ P-value } & & 0.0002 & $<.0001$ & 0.0002 & $<.0001$ & 0.0002 \\
\hline R.PL & $\mathrm{CA}$ & 0 & $38.70^{\mathrm{bc}} \pm 2.69$ & $77.28^{\mathrm{a}} \pm 4.88$ & $61.30^{\mathrm{ab}} \pm 2.69$ & $22.72^{c} \pm 4.88$ & $29.10^{\mathrm{ab}} \pm 0.24$ \\
\hline R.PL & $\mathrm{CA}$ & 1.5 & $37.41^{b c} \pm 2.13$ & $75.83^{\mathrm{a}} \pm 3.94$ & $62.59^{\mathrm{ab}} \pm 2.13$ & $24.17^{\mathrm{c}} \pm 3.94$ & $29.43^{\mathrm{ab}} \pm 0.67$ \\
\hline R.PL & $\mathrm{CA}$ & 3 & $33.71^{b c} \pm 2.90$ & $64.49^{\mathrm{b}} \pm 2.14$ & $66.29^{\mathrm{ab}} \pm 2.90$ & $35.51^{\mathrm{b}} \pm 2.14$ & $29.76^{\mathrm{ab}} \pm 0.59$ \\
\hline R.PL & FUA & 0 & $38.70^{\mathrm{bc}} \pm 2.69$ & $77.28^{\mathrm{a}} \pm 4.88$ & $61.30^{\mathrm{ab}} \pm 2.69$ & $22.72^{c} \pm 4.88$ & $29.09^{\mathrm{ab}} \pm 0.24$ \\
\hline R.PL & FUA & 1.5 & $37.07^{b c} \pm 0.15$ & $75.54^{\mathrm{a}} \pm 1.31$ & $62.93^{\mathrm{ab}} \pm 0.15$ & $24.46^{\mathrm{c}} \pm 1.31$ & $29.83^{\mathrm{ab}} \pm 0.47$ \\
\hline R.PL & FUA & 3 & $27.14^{\mathrm{c}} \pm 3.78$ & $51.06^{\mathrm{c}} \pm 2.98$ & $72.86^{\mathrm{a}} \pm 3.78$ & $48.94^{\mathrm{a}} \pm 2.98$ & $30.44^{\mathrm{a}} \pm 0.69$ \\
\hline L.PL & $\mathrm{CA}$ & 0 & $54.58^{\mathrm{a}} \pm 2.09$ & $81.39^{\mathrm{a}} \pm 1.80$ & $45.42^{\mathrm{c}} \pm 2.09$ & $18.61^{\mathrm{c}} \pm 1.80$ & $28.43^{\mathrm{b}} \pm 0.25$ \\
\hline L.PL & $\mathrm{CA}$ & 1.5 & $39.85^{b c} \pm 3.52$ & $80.16^{\mathrm{a}} \pm 1.19$ & $60.15^{\mathrm{ab}} \pm 3.52$ & $19.84^{\mathrm{c}} \pm 1.19$ & $29.16^{\mathrm{ab}} \pm 0.47$ \\
\hline L.PL & $\mathrm{CA}$ & 3 & $37.60^{\mathrm{bc}} \pm 1.83$ & $75.56^{\mathrm{a}} \pm 3.08$ & $62.40^{\mathrm{ab}} \pm 1.83$ & $24.44^{\mathrm{c}} \pm 3.08$ & $29.50^{\mathrm{ab}} \pm 0.35$ \\
\hline L.PL & FUA & 0 & $54.58^{\mathrm{a}} \pm 2.09$ & $81.39^{\mathrm{a}} \pm 1.79$ & $45.42^{c} \pm 2.09$ & $18.61^{\mathrm{c}} \pm 1.79$ & $28.43^{\mathrm{b}} \pm 0.25$ \\
\hline L.PL & FUA & 1.5 & $43.63^{\mathrm{ab}} \pm 5.30$ & $75.94^{\mathrm{a}} \pm 5.53$ & $56.37^{b c} \pm 5.30$ & $24.06^{\mathrm{c}} \pm 5.53$ & $29.26^{\mathrm{ab}} \pm 0.46$ \\
\hline L.PL & FUA & 3 & $30.74^{b c} \pm 10.65$ & $70.78^{\mathrm{ab}} \pm 3.49$ & $69.26^{\mathrm{ab}} \pm 10.65$ & $29.22^{\mathrm{bc}} \pm 3.49$ & $30.30^{\mathrm{a}} \pm 0.75$ \\
\hline SEM & & & \pm 1.66 & \pm 1.61 & \pm 1.66 & \pm 1.61 & \pm 0.13 \\
\hline P-value & & & 0.0023 & $<.0001$ & 0.0023 & $<.0001$ & 0.0093 \\
\hline \multicolumn{3}{|c|}{ Interactions } & \multicolumn{4}{|c|}{ P-value } & \\
\hline \multicolumn{3}{|c|}{ PL X OAT } & 0.7914 & 0.6919 & 0.7914 & 0.6919 & 0.8942 \\
\hline \multicolumn{3}{|c|}{ PL X OAL } & 0.0881 & 0.0246 & 0.0881 & 0.0246 & 0.7092 \\
\hline \multicolumn{3}{|c|}{ OAT X OAL } & 0.3315 & 0.1647 & 0.3315 & 0.1647 & 0.4388 \\
\hline \multicolumn{3}{|c|}{ PL X OAT X OAL } & 0.9154 & 0.4217 & 0.9154 & 0.4217 & 0.9461 \\
\hline
\end{tabular}

${ }^{1}$ PL: Protein Level (Recommended, RPL or Low, LPL).

${ }^{2}$ OAT: Organic Acid Type (CA, Citric Acid \& FUA, Fumaric Acid).

${ }^{3}$ OAL: Organic Acid Level (0, $\left.1.5 \& 3 \%\right)$.

Means with different superscripts within the column of each classification (PL, OAL or combined effects) are significantly $(\mathrm{P} \leq 0.05)$ different.

\section{Bone Ash:}

Tibia bone ash percentage was significantly affected $(\mathrm{P} \leq 0.05)$ by $\mathrm{PL}$ and $\mathrm{OAL}$; however, OAT did not affect tibia ash (Table 5). Recommended PL diet or OA supplemented diets (1.5 and 3.0\%) increased tibia ash (\%) in comparison with LPL or $0 \%$ OA diets, respectively. Acidification of recommended or low protein diets with $\mathrm{CA}$ or FUA acids $(1.5$ or $3.0 \%)$ increased tibia bone ash percentages; as the highest values recorded with RPL or LPL $+3.0 \%$ FUA diets.

\section{DISCUSSION}

The results of the current study indicated significant improvements in live body weight by feeding RPL diet (NRC, 1994) compared with LPL diet $(2 \%$ less). Corzo et al. (2005) reported that broiler chicks fed low crude protein diets were not able to achieve growth as those fed high crude 
protein without adding a certain amount of nonessential amino acids in their diets. Values reported for performance agreed with those of Rashid et al. (2012) who reported that lowering CP by $2 \%$ resulted in decreasing growth performance of Cobb and Hubbard strains. However, Abbasi et al. (2014) observed that dietary $\mathrm{CP}$ level could be reduced up to $10 \%$ (of the recommended requirements) after the starter period without any detrimental influence on growth performance of broiler chicks.

Values observed in this study revealed that OAT (citric or fumaric) had no significant effect on body weight values. This agreed with $\mathrm{PinWu}$ and Chen (2016) who demonstrated that diets supplemented with $1.0 \%$ CA or FUA did not affect turkeys' growth performance. Also, Rafacz-Livingston et al. (2005) reported that growth performance parameters were not significantly affected by dietary $2.0-4.0 \%$ CA. The current study did not show any improvement in chicks' body weight when OA level increased from 1.5 to $3.0 \%$. Abdel-Fattah et al. (2008) showed that $1.5 \%$ commercial acetic, citric or lactic acid improved broiler performances; however, increasing OA level up to $3.0 \%$ had no further improvements. They reported that organic acids reduced the $\mathrm{pH}$ reducing property. Also, Biggs and Parsons (2008) observed that broilers fed $4.0 \% \mathrm{CA}$ diet showed a reduction in growth while $3.0 \%$ CA had no significant effect. They concluded that dietary organic acids effect was inconsistent growth performance. Conversely, Sultan et al. (2015) reported an increment in body weight with increasing organic acid level supplementation.

Results of this study suggest declared that supplementation of OA in RPL diet was effective on live body weight; however, supplementation in LPL diet had inconsistent and insignificant improvements. Citric acid supplementation affected live body weight in the starter phase while FUA affected LBW in the grower and finisher phases. This could be attributed to a better use of nutrients when organic acids added to the diet. Ricke (2003) reported that dietary organic acids could suppress the growth of certain species of bacteria, particularly those acids intolerant such as $E$. coli, Salmonella sp. and Campylobacter sp. The principal benefit of organic acids was to lower stomach and intestines $\mathrm{pH}$ so that the gut environment became too acidic for bacterial growth. The antibacterial effect of organic acids is due to its effect on the membrane or macromolecules of the microbial cell and intervenes with the nutrient transport and energy metabolism. Moreover, Mellor (2000) stated that organic acids improved protein digestion in the young animal by stimulating pancreatic enzyme secretion.

The results revealed that LPL diet significantly decreased plasma total protein, albumin, total lipids and calcium; however, uric acid and phosphorous concentrations increased. Plasma protein content reported herein was within the normal range (2.5 and $5.5 \mathrm{~g} / \mathrm{dl}$ ) and was an indicator of birds' health status. Low plasma protein content indicates poor diets, malnutrition and disorder conditions. At low protein intake, albumin works as reservoir and source of protein and contributes to the colloidal osmotic pressure, acid-base balance and carrier for small molecules such as vitamins, minerals, hormones and fatty acids (Sturkie, 1986). Results obtained herein agreed with those of Malomo et al. (2013) who demonstrated that reducing dietary protein level with addition of essential amino acids (22, 20, 18 and 16) increased serum uric acid. They attributed that to the reduction in bio-availability of an individual or group protein supply in the diets. However, Darsi et al. (2012) found that chicks fed low CP diet had lower blood plasma uric acid concentration. Blood uric acid is a deductive measure for estimating the bioavailability of protein sources for broilers; the high biological values of dietary protein sources reduces the uric acid content in the blood serum compared with low biological values (Hevia and Clifford, 1977). Also, uric acid blood levels are well known to be inconsistent (Sturkie, 1986). Liver function enzymes (AST and ALT) were not affected by decreasing $2 \%$ of the dietary protein, indicating that LPL was still safe to the broilers. Saleh (2016) reported that plasma concentrations of GOT, GPT and total cholesterol were not affected by $1.0 \%$ reduction in dietary protein level. Dehghani-Tafti and Jahanian (2016) showed that reducing dietary CP level resulted in increasing $(\mathrm{P} \leq 0.001)$ serum triglycerides, decreasing $(\mathrm{P} \leq 0.001)$ serum uric acid concentrations while cholesterol was not affected.

Plasma total protein, uric acid and calcium increased $(\mathrm{P} \leq 0.05)$ while albumin and phosphorus levels decreased $(\mathrm{P} \leq 0.05)$ by $\mathrm{CA}$ addition in comparison with FUA. Besides, liver functions were not adversely altered by OAT addition. Also, data showed that OA at 1.5 or $3.0 \%$ reduced cholesterol, AST and ALT in comparison with $0 \%$ OA while total protein, uric acid, calcium and phosphorus increased. Results were consistent with some findings and conflict with others. PinWu and Chen (2016) demonstrated no significant differences in serum calcium and phosphorous concentrations when turkey diets supplemented with $1.0 \%$ of CA or FUA. Besides, Kamal and Ragaa (2014) reported significant reductions in serum total lipids and cholesterol due to dietary acidification of $3.0 \%$ butyric, fumaric or lactic acids. The positive role of organic acids in lowering the blood lipids and cholesterol could be due to their capacity in reducing the $\mathrm{pH}$ resulting from microbial intracellular activities. Therefore, OA inhibits the action of the microbial enzymes so the bacteria cell use energy to release the acid anions, resulting in accumulation of acid anions (Young and Foegeding, 1993). However, Nourmohammadi et al. (2010) reported that dietary inclusion of CA (3.0 and 6.0\%) significantly affected cholesterol concentration but had no significant effect on AST, ALT, triglycerides, total protein and $\mathrm{Ca}$ plasma concentrations. Moreover, Ghazalah et al. (2011) reported that dietary $0.5 \%$ formic, $0.5 \%$ fumaric, $0.75 \%$ acetic and $1.0-2.0 \%$ citric acids 
significantly increased blood serum calcium, phosphorus and total protein. Besides, Adil et al. (2010) showed that 2.0 or $3.0 \%$ fumaric acid supplementation increased serum calcium and phosphorus concentrations. Also, Abdel-Fattah et al. (2008) reported that chicks fed acidified diets (acetic, citric, lactic acid) had significantly higher serum calcium and phosphorus concentrations. They related that effect to the reduction in the $\mathrm{pH}$ of the gut by the $\mathrm{OA}$ and the increased absorption of macro elements. The variation between the finding of this study and others might be due to the differences in feed ingredients and management conditions. On the contrary, Islam et al. (2012) did not find any significant effect of citric acid (up to $0.75 \%$ ) on minerals blood profile. Variations in the results explained by Islam et al. (2012) suggested that despite boosting bioavailability of calcium and phosphorus, the homeostasis by endocrine regulation responsible for maintaining the blood level of these elements.

Diets different in $\mathrm{CP}$ and supplemented with OA had no adverse effect on broiler chicks' blood biochemical constituents and growth performance. Moreover, supplementation of FUA (3.0\%) to LPL diet improved liver function. Similarly, many reports declared that feeding OA to broilers enhanced their performance and immune response (Kamal and Ragaa, 2014 and Hassan et al., 2015). Although, organic acids are not antibiotics, they could be a useful tool (if used correctly along with nutritional and managerial precautions) in maintaining the health of birds' digestive tract, resulting in improving their performance.

Report of this study showed low-fat content in meat with RPL diet and supplementation of OA with RPL or LPL. Chickens fed high CP diet had low-fat meat of breast, thighs and total carcass contents (Darsi et al., 2012). The low-fat meat resulted from diets high in protein level could be attributed to increasing the heat increment associated with the deamination and transamination of remaining amino acids to other metabolites. Further, Ragab et al. (2012) found that feeding diet with the recommended $\mathrm{CP}$ level increased fat and decreased protein and ash whereas suboptimal level ( $2 \%$ less) increased protein and ash and decreased fat of chicks' meat. On the contrary, Kamran et al. (2008) reported that feeding diets with different CP levels $(23 \%, 22 \%, 21 \%$ and $20 \%$ ) had no significant effects on broiler chicks' body composition.

Significant improvements in $\mathrm{N}$ and $\mathrm{P}$ retention observed with RPL diet in comparison with LPL ones. These results contradicted with the finding of Saleh (2016) who stated that lowering CP by $1.0 \%$, at constant ME and the same essential amino acids content, improved crude protein utilization. Besides, Gheisari et al. (2015) reported that reducing dietary $\mathrm{CP}$ decreased nitrogen excretion. Furthermore, Hernández et al. (2013) showed that reducing dietary CP by $1.5 \%$ of the diet resulted in a $4.8 \%$ reduction in $\mathrm{N}$ excretion. Also, Malomo et al. (2013) concluded that broilers fed $20 \% \mathrm{CP}$ diet achieved the best $(\mathrm{P}<0.05) \mathrm{N}$ retention and percentage of fecal $\mathrm{N}$; further reduction in $\mathrm{CP}$ reduced $\mathrm{N}$ intake and output amount. There is a limit to which dietary CP could be brought down with no negative impact on the performance and protein economy although the requirements of methionine and lysine had secured because other amino acids may be limited. Similarly, Kermanshahi et al. (2011) demonstrated that dietary CP levels (17.70, 20.80 and 23.97\%) significantly affected $\mathrm{P}, \mathrm{Ca}$ and $\mathrm{N}$ retention; the increments in $\mathrm{CP}$ level (23.97\%) significantly reduced $\mathrm{P}, \mathrm{Ca}$ and $\mathrm{N}$ retention. Also, Corzo et al. (2005) reported improvements in dietary $\mathrm{N}$ intake, excretion and retention when low $\mathrm{CP}$ diet fed to broilers.

A significant reduction in tibia bone ash observed with LPL compared to RPL diets. These results agreed with Ragab et al. (2012) who found that higher tibia ash, density, $\mathrm{Ca}$ and $\mathrm{P}$ values obtained when the recommended $\mathrm{CP}$ diet fed compared with the suboptimal CP diet ( $2 \%$ less). In the same manner, Ziaei et al. (2011) reported that tibia bone ash decreased with reducing CP in the diet. However, Kermanshahi et al. (2011) reported that high dietary CP $(23.97 \%)$ or low (17.70\%) decreased the length of tibia bone and tibia bone P; however, tibia bone ash was not affected.

The current data revealed that FUA or $3.0 \% \mathrm{OA}$ supplemented diets were more effective in reducing $\mathrm{N}$ and $\mathrm{P}$ excretion and increasing $\mathrm{N}$ and $\mathrm{P}$ retention, as well as tibia bone ash, compared with $\mathrm{CA}$ or 0 and $1.5 \%$ OA. Furthermore, supplementing CA or FUA with both $\mathrm{CP}$ levels improved tibia bone ash and retention of $\mathrm{N}$ and $\mathrm{P}$; the highest values were obtained from RPL or LPL $+3.0 \%$ FUA diets compared to the rest of the treatments. These results revealed that $\mathrm{OA}$ supplementation to broiler diets reduced $\mathrm{N}$ and $\mathrm{P}$ excretions which would have a positive effect on reducing the environmental pollution.

The results obtained from the present study agreed with earlier reports (Hossain and Nargis, 2016) that OA blend added to broiler diets enhanced their bone development (as relative weight or length). However, with male turkey poults, PinWu and Chen (2016) reported that $1.0 \%$ CA resulted in higher bone ashes and calcium content (relative to bone ash) as compared to $1.0 \%$ FUA. Acidification of broiler diets with 2.0\% CA (Ragab et al., 2012) improved tibia quality parameters. Addition of citric acid up to $0.75 \%$ to broiler diet increased calcium and phosphorus absorption; besides, bone ash, mineral density and strength were increased; further addition of acid resulted in absorption decline (Islam et al., 2012). The beneficial effects of FUA $(0.5,1$ and $1.5 \%)$ or $\mathrm{CA}(1.0,2.0$ and $3.0 \%)$ on nutrient utilization were also reported by Ghazalah et al. (2011). Citric acid was more effective with diets deficient in $\mathrm{P}$ as reported by Liem et al. (2008) who demonstrated that citric, malic or fumaric acids increased tibia ash (by increasing $\mathrm{Ca}$ and $\mathrm{P}$ retention) in broiler chickens fed a diet deficient in $\mathrm{P}$ with a 
significant effect of CA only. They attributed the bone improvements to that citric acid is a chelator and can increase $\mathrm{Ca}$ absorption from the intestine, so, increases bone growth. Also, Rafacz-Livingston et al. (2005) reported that tibia ash increased $(\mathrm{P}<0.05)$ with increasing $\mathrm{CA}$ from 0 to $4.0 \%$; $\mathrm{CA}$ improved phosphorus utilization and mineral concentration in the tibia.

In conflict with our results, the addition of $1.5 \%$ organic acid mixture (containing 64\% formic and $25 \%$ propionic acid) to broiler diet did not affect the apparent ileal absorption of minerals (except for a tendency to lower $\mathrm{P}$ absorption), tibia mineral content, and tibia quality parameters (Hafeez et al., 2014). Also, Wickramasinghe et al. (2014) reported that $2 \% \mathrm{CA}$ in broiler diet did not affect $\mathrm{N}$ and $\mathrm{P}$ retention. In the same manner, Smulikowska et al. (2010) stated that dietary organic acid blend (CA, lactic and formic acids) did not affect digesta $\mathrm{pH}$, tibia ash and tibia maximum strength in broilers.

\section{CONCLUSION}

Supplementation of organic acids (fumaric and citric) at different levels $(0,1.5$ and $3 \%)$ to broiler diets differing in crude protein levels (recommended and low) had beneficial effects on growth, meat chemical composition, blood plasma parameters, tibia bone ash and retention of $\mathrm{N}$ and $\mathrm{P}$. The addition of $3 \%$ fumaric acid improved liver function, increased tibia ash and reduced $\mathrm{N}$ and $\mathrm{P}$ excretion, resulted in a favorable environment. Therefore, the utilization of different organic acid type and levels as a feed additive in poultry diets vary in CP levels could be recommended.

\section{REFERENCES}

Abbasi, M.A., A.H. Mahdavi, A.H. Samie, and R. Jahanian, 2014. Effects of different levels of dietary crude protein and threonine on performance, humoral immune responses and intestinal morphology of broiler chicks. Rev. Bras. Cienc. Avic. 16, (1) 35-44.

Abdel-Fattah, S.A., M.H., EI-Sanhoury, N.M., EIMednay, and F. Abdul-Azeem, 2008. Thyroid activity, some blood constituents, organs morphology and performance of broiler chicks fed supplemental organic acids. Int. J. Poult. Sci.7, (3) 215-222.

Adil, S., B. Tufail, A.B. Gulam, S. Masood, and R. Manzoor, 2010. Effect of dietary supplementation of organic acids on performance, intestinal histomorphology, and serum biochemistry of broiler chicken. Vet. Med. Int. 1-7.

A.O.A.C., 1990. Official Methods of Analysis, $15^{\text {th }}$ ed. Association of Official Analytical Chemist, Washington, DC.

Biggs, P. and C.M. Parsons, 2008. The effects of several organic acids on growth performance, nutrient digestibilities, and cecal microbial populations in young chicks. Poult. Sci. 87, (12) 2581-2589

Bregendahl, K., J.L. Sell, and D.R. Zimmerman, 2002. Effect of low-protein diets on growth performance and body composition of broiler chicks. Poult. Sci. 81, (8) 1156-1167.

Corzo, A., C.A. Fritts, M.T. Kidd, and B.J Kerr, 2005. Response of broiler chicks to essential and non-essential amino acid supplementation of low crude protein diets. Anim. Feed Sci. Technol. 118, (3) 319-327.

Darsi, E., M. Shivazad, M. Zaghari, N.F. Namroud, and R. Mohammadi, 2012. Effect of reduced dietary crude protein levels on growth performance, plasma uric acid and electrolyte concentration of male broiler chicks. J. Agric. Sci. Technol. 14, (4) 789-797.

Dehghani-Tafti, N. and R. Jahanian, 2016. Effect of supplemental organic acids on performance, carcass characteristics, and serum biochemical metabolites in broilers fed diets containing different crude protein levels. Anim. Feed Sci. and Technol. 211, 109-116.

Duncan, D.B., 1955. Multiple range and multiple F test. Biometrics, 11, (1) 1-42.

Ghazalah, A.A., A.M. Atta, M. Kout Elkloup, El. Moustafa, and R.F.H. Shata, 2011. Effect of dietary supplementation of organic acids on performance, nutrients digestibility and health of broiler chicks. Int. J. Poult. Sci. 10, (3) 176-184.

Gheisari, H.R., K. Asasi, I. Mostafa, and E. Mohsenifard, 2015. Effect of different levels of dietary crude protein on growth performance, body composition of broiler chicken and low protein diet in broiler chicken. Int. J. Poult. Sci. 14, (5) 285-292.

Hafeez, A., A. Mader, F. Goodarzi Boroojeni, I. Ruhnke, I. Rohe, K. Manner, and J. Zentek, 2014. Impact of thermal and organic acid treatment of feed on apparent ileal mineral absorption, tibial and liver mineral concentration, and tibia quality in broilers. Poult. Sci. 93, 1754-1763.

Hassan, H.M.A., A.W. Youssef, H.M. Ali, and M.A. Mohamed, 2015. Adding phytogenic material and/or organic acids to broiler diets: Effect on performance, nutrient digestibility and net profit. Asian J. Poult. Sci. 9, (2) 97-105.

Hernández, F., M.D. Megias, J. Orengo, S. Martinez, M.J. Lopez, and J. Madrid, 2013. Effect of dietary protein level on retention of nutrients, growth performance, litter composition and $\mathrm{NH}_{3}$ emission using a multi-phase feeding programme in broilers. Spanish J. Agric. Res. 11, (3) 736-746.

Hevia, P. and J. Clifford, 1977. Protein intake, uric acid metabolism and protein efficiency ratio in growing chicks. J. Nutr. 107, (6) 959-964.

Hossain, M.E. and F. Nargis, 2016. Supplementation of organic acid blends in water improves growth, meat yield, dressing parameters and bone development of broilers. Bangladesh. J. Anim. Sci. 45 , (1) 7-18. 
Islam, K.M.S., H. Schaeublin, C. Wenk, M. Wanner, and A. Liesegang, 2012. Effect of dietary citric acid on the performance and mineral metabolism of broiler. J. Anim. Physiol. Anim. Nutr. 96, (5) 808-817.

Kamal, A.M. and N.M. Ragaa, 2014. Effect of Dietary Supplementation of Organic Acids on Performance and Serum Biochemistry of Broiler Chicken. Nat. Sci. 12, (2) 38-45.

Kamran, Z., M. Sarwar, M. Nisa, M.A. Nadeem, T. Mushtaq, T. Ahmed, M.E. Babar, and M.M.H. Mushtaq, 2008. Effect of low levels of dietary protein on growth, protein utilisation and body composition of broiler chicks from one to twentysix days of age. Avian Biol. Res. 1, (1) 19-25.

Kermanshahi, H., N. Ziaei, and M. Pilevar, 2011. Effect of dietary crude protein fluctuation on performance, blood parameters and nutrients retention in broiler chicken during starter period. Glob. Veterinaria, 6, (2) 162-167.

Liem, A., G.M. Pesti, and H.M. Edwards, 2008. The effect of several organic acids on phytase phosphorus hydrolysis in broiler chicks. Poult. Sci. 87, (4) 689-693.

Malomo, G.A., S.A. Bolu, and S.G. Olutade, 2013. Effects of dietary crude protein on performance and nitrogen economy of broilers. Sustainable Agric. Res. 2, (3) 52-57.

Marcu, A., I. Vacaru-Opriş, G. Dumitrescu, L.P. Ciochină, A. Marcu, M. Nicula, I. Peţ, D. Dronca, B. Kelciov, and C. Mariş, 2013. The influence of genetics on economic efficiency of broiler chickens growth. Anim. Sci. Biotechnologies, 46, (2) 339-346.

Mellor, S., 2000. Nutraceuticals-alternatives to antibiotics. World Poult. 16, (2) 30-33.

National Research Council, NRC, 1994. Nutrient Requirements of Poultry. $9^{\text {th }}$ revised ed. National Academic Press. Washington, DC. USA

Nourmohammadi, R., S.M. Hosseini, and H. Farhangfar, 2010. Effect of dietary acidification on some blood parameters and weekly performance of broiler chickens. J. Anim. Vet. Adv. 9, 3092-3097.

PinWu, C. and L.K., Chen, 2016. Effects of dietary citric acid, fumaric acid or sodium bicarbonate on growth performance and bone characteristics in male turkey poult. J. Chin. Soc. Anim. Sci. 45, (3) 187-196.

Rafacz-Livingston, K.A., C. Martinez-Amezcua, C.M. Parsons, D.H. Baker, and J. Snow, 2005. Citric acid improves phytate phosphorus utilization in crossbred and commercial broiler chicks. Poult. Sci. 84, (9) 1370-1375.

Ragab, M.S., H.M. Abdel wahed, E.M. Omar, and W.H.A. Mohamed, 2012. Effect of adding citric and lactic acids to broiler diets different in their protein content on productive performance, bacterial count and some blood parameters. Egypt. J. Nutr. Feeds, 15, (3) 613-629.

Rashid, H.S., E.M. Huwaida, and A.Y. Ibrahim, 2012. Effect of dietary protein level and strain on growth performance of heat stressed broiler chicks. Int. J. Poult. Sci. 11, (10) 649-653.

Ricke, S.C., 2003. Perspective on the use of organic acids and short chain fatty acids as antimicrobials. Poult. Sci. 82, (4) 632-639.

Saleh, A.A., 2016. Effect of low-protein in isoenergetic diets on performance, carcass characteristics, digestibilities and plasma lipids of broiler chickens. Egypt. Poult. Sci. 36, (1) 251262.

SAS. 2006. Statistical Analysis System, SAS User's Guide: Statistics. SAS Institute Inc. Editors, Cary, NC.

Smulikowska, S., J. Czerwinski, and A. Mieczkowska, 2010. Effect of an organic acid blend and phytase added to a rapeseed cakecontaining diet on performance, intestinal morphology, caecal microflora activity and thyroid status of broiler chickens. J. Anim. Physiol. Anim. Nutr. 94, (1) 15-23

Sturkie, P.D., 1986. Avian Physiology, fourth ed. Springer-Verlag, Inc., New Work, NY.

Sultan, A., T. Ullah, S. Khan, and R.U. Khan, 2015. Effect of organic acid supplementation on the performance and ileal microflora of broiler during finishing period. Pakistan J. Zool. 47, (3) 635639.

Wickramasinghe, K.P., N.S.B.M. Atapattu, and R.T. Seresinhe, 2014. Effects of citric acid on growth performance and nutrient retention of broiler chicken fed diets having two levels of nonphytate phosphorus and rice bran. Iran. J. Appl. Anim. Sci. 4, (4) 809-815.

Young, K.M. and P.M. Foegeding, 1993. Acetic, lactic and citric acids and $\mathrm{pH}$ inhibition of Listeria monocytogenes Scott A. and the effect on intracellular pH. J. Appl. Bacteriol., 74, 515-520.

Young, D.S. and R.B. Friedman, 2001. Effects of disease on clinical laboratory tests fourth ed., Vol. 1, Washington, DC.

Ziaei, N., H. Kermanshahi, and M. PileVar, 2011. Effects of dietary crude protein and calcium/phosphorus content on growth, nitrogen and mineral retention in broiler chickens. Afr. J. Biotechnol. 10, (61) 13342-13350. 
تأثير مستوي بروتين العليقة وبعض الأحماض العضوية علي أداء بداري اللحم هيام سيد عبد الحليم، فاتن عبد العزيز محمود، حماده صلاح صابر محمد، إسماعيل حافظ هرمس قسم الإنتاج الحيواني والثروة السمكية، كلية الزراعة، جامعة قناة السويس

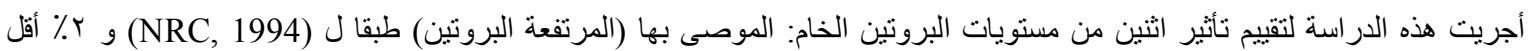

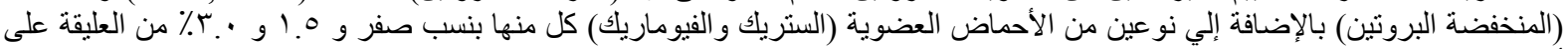

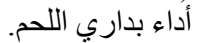

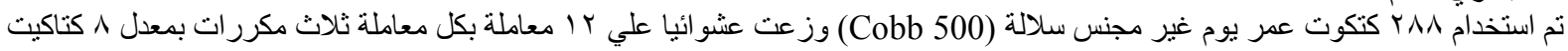

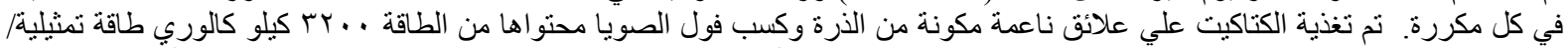

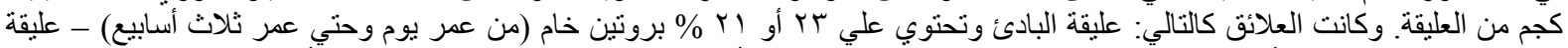

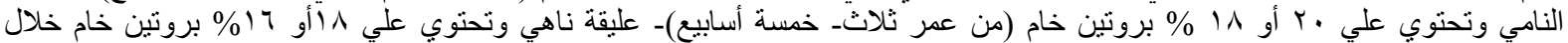
الأسبوع السادس. ويمكن تلخيص النتائج فيما يلي:-

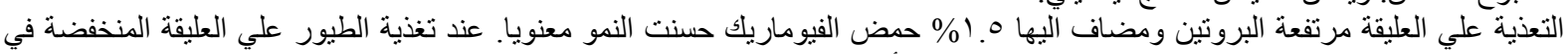

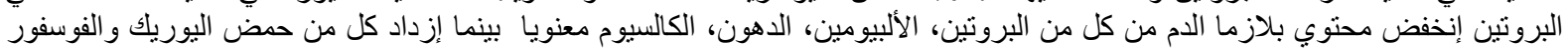

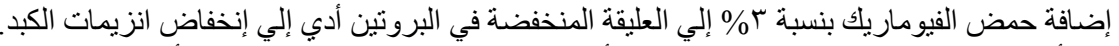

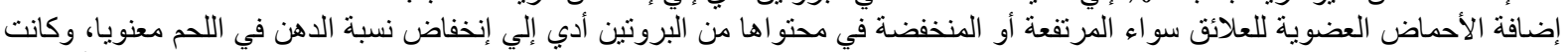

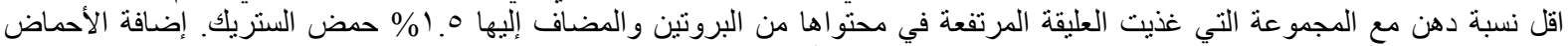

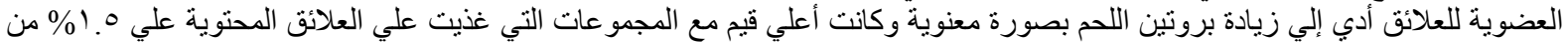

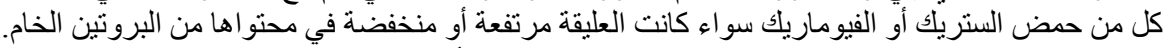

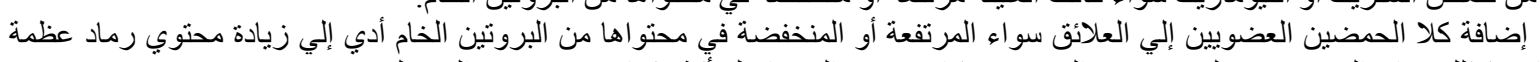

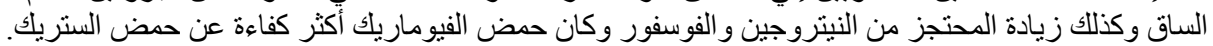

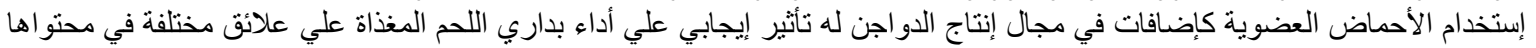

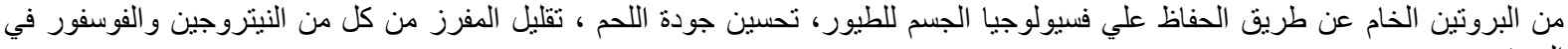


Egyptian J. Anim. Prod. (2018) 55(1):15-27

Issued by The Egyptian Society of Animal Production 